Approved for public release.

Distribution is unlimited.

\title{
Investigation of Sorption and Diffusion \\ Mechanisms, and \\ Preliminary Economic \\ Analysis
}

Fuel Cycle Research \& Development

Prepared for

U.S. Department of Energy Material Recovery and Waste Form Development Campaign R. Bhave, R. T. Jubin, B. Spencer, Oak Ridge National Laboratory S. Nair, Georgia Institute of Technology January 20, 2017 FCRD-MRWFD-2017-000399 ORNL/SR-2017/59 


\section{DOCUMENT AVAILABILITY}

Reports produced after January 1, 1996, are generally available free via US Department of Energy (DOE) SciTech Connect.

Website http://www.osti.gov/scitech/

Reports produced before January 1, 1996, may be purchased by members of the public from the following source:

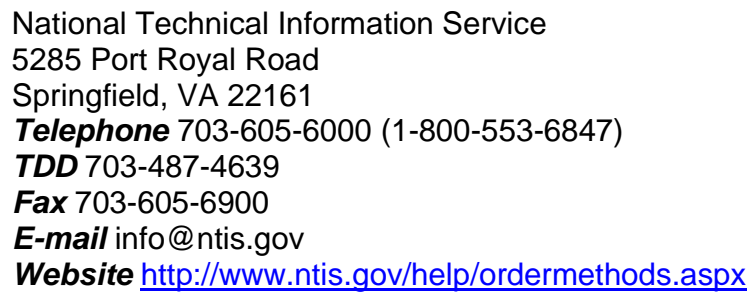

Reports are available to DOE employees, DOE contractors, Energy Technology Data Exchange representatives, and International Nuclear Information System representatives from the following source:

Office of Scientific and Technical Information

PO Box 62

Oak Ridge, TN 37831

Telephone 865-576-8401

Fax 865-576-5728

E-mail reports@osti.gov

Website http://www.osti.gov/contact.html

\section{DISCLAIMER}

This report was prepared as an account of work sponsored by an agency of the United States Government. Neither the United States Government nor any agency thereof, nor any of their employees, makes any warranty, express or implied, or assumes any legal liability or responsibility for the accuracy, completeness, or usefulness of any information, apparatus, product, or process disclosed, or represents that its use would not infringe privately owned rights. Reference herein to any specific commercial product, process, or service by trade name, trademark, manufacturer, or otherwise, does not necessarily constitute or imply its endorsement, recommendation, or favoring by the United States Government or any agency thereof. The views and opinions of authors expressed herein do not necessarily state or reflect those of the United States Government or any agency thereof. 
Investigation of Sorption and Diffusion Mechanisms, and Preliminary Economic Analysis January 20, 2017 


\section{SUMMARY}

This report describes the synthesis and evaluation of molecular sieve zeolite membranes to separate and concentrate tritiated water (HTO) from dilute HTO-bearing aqueous streams. Several monovalent and divalent cation exchanged silico alumino phosphate (SAPO-34) molecular sieve zeolite membranes were synthesized on disk supports and characterized with gas and vapor permeation measurements. The pervaporation process performance was evaluated for the separation and concentration of tritiated water.

Experiments were performed using tritiated water feed solution containing tritium at the high end of the range $(1 \mathrm{mCi} / \mathrm{mL})$ anticipated in a nuclear fuel processing system that includes both acid and water streams recycling. The tritium concentration was about $0.1 \mathrm{ppm}$. The permeate was recovered under vacuum. The $\mathrm{HTO} / \mathrm{H}_{2} \mathrm{O}$ selectivity and separation factor calculated from the measured tritium concentrations ranged from 0.99 to 1.23 , and 0.83-0.98, respectively. Although the membrane performance for HTO separation was lower than expected, several encouraging observations including molecular sieving and high vapor permeance are reported. Additionally, several new approaches are proposed, such as tuning the sorption and diffusion properties offered by small pore LTA zeolite materials, and cation exchanged aluminosilicates with high metal loading. It is hypothesized that substantially improved preferential transport of tritium (HTO) resulting in a more concentrated permeate can be achieved. Preliminary economic analysis for the membrane-based process to concentrate tritiated water is also discussed. 
Investigation of Sorption and Diffusion Mechanisms, and Preliminary Economic Analysis

\section{CONTENTS}

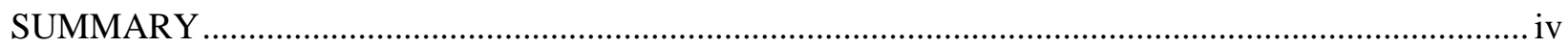

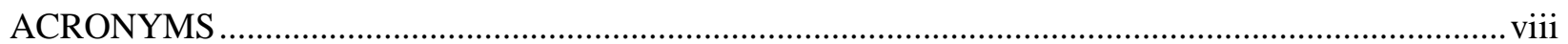

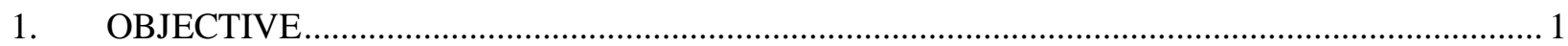

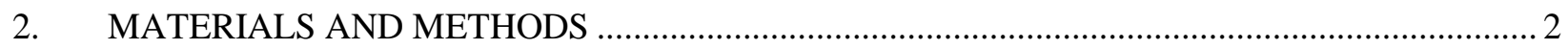

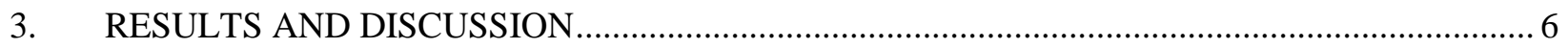

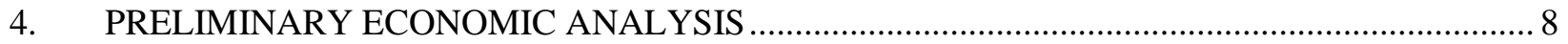

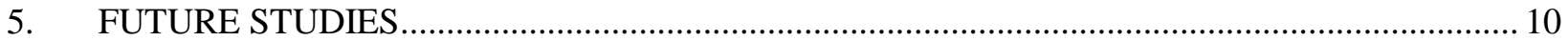




\section{FIGURES}

Figure 1. Schematic of the pervaporation system for the separation of tritiated water............................... 6

Figure 2. Schematic of a cascade system showing membrane based concentration of tritiated

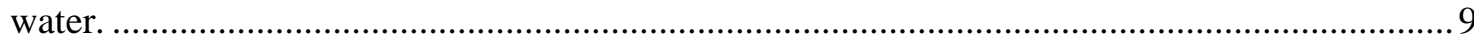




\section{TABLES}

Table 1. Composition and single gas permeance of SAPO-34 membranes before and after ion

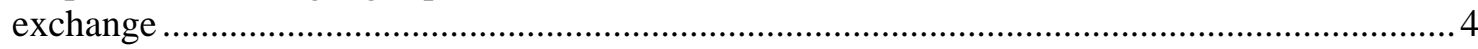

Table 2. Gas permeance of neutral SAPO-34, monovalent, and divalent cation exchange SAPO-

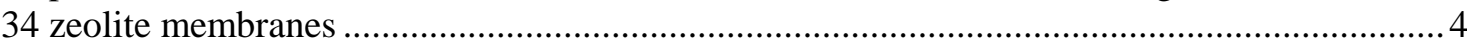

Table 3. Vapor permeation characteristics of SAPO-34 monovalent ion exchange SAPO-34

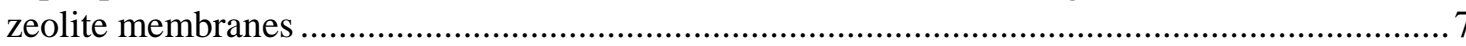

Table 4. Vapor permeation characteristics of SAPO-34 divalent cation exchange SAPO-34 zeolite

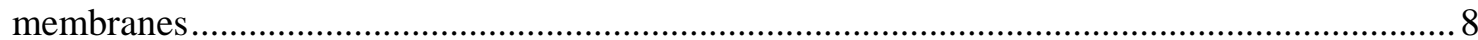

Table 5. Preliminary estimate of membrane area and stages for the concentration of tritiated water ..........9 


\section{ACRONYMS}

$\begin{array}{ll}\mathrm{Al}_{2} \mathrm{O}_{3} & \text { alumina } \\ \mathrm{Bq} & \text { Becquerel } \\ \mathrm{CECE} & \text { combined electrolysis and catalyst exchange } \\ \mathrm{D}_{2} \mathrm{O} & \text { deuterium oxide } \\ \mathrm{DPA} & \text { di- } n \text {-propylamine } \\ \mathrm{FTIR} & \text { Fourier Transform Infrared Spectroscopy } \\ \mathrm{GPU} & \text { gas permeation unit }\left(\mathrm{cm}^{3} / \mathrm{cm}^{2}-\mathrm{sec}-\mathrm{cm} \mathrm{Hg}\right) \\ \mathrm{HDO} & \text { heavy (or deuterated) water } \\ \mathrm{H}_{2} \mathrm{O} & \text { water containing only hydrogen-1 } \\ \mathrm{H}_{3} \mathrm{PO} & \text { phosphoric acid } \\ \mathrm{HTO} & \text { tritiated water } \\ \mathrm{ISS} & \text { isotope separation system } \\ \mathrm{ITER} & \text { international thermonuclear experimental reactor } \\ \mathrm{LSA} & \text { liquid scintillation analyzer } \\ \mathrm{LTA} & \text { Linde type A } \\ \text { LUDOX } & \text { colloidal silica } \\ \text { mCi } & \text { milli Curie }\left(3.7 \times 10^{7} \text { Bq) }\right. \\ \text { PMR } & \text { palladium membrane reactor } \\ \mathrm{P}_{2} \mathrm{O}_{5} & \text { phosphorus pentoxide } \\ \text { SAPO-34 } & \text { silico alumino phosphate zeolite } \\ \mathrm{SiO} & \text { silica } \\ \text { TEAOH } & \text { triethyl aluminum hydroxide } \\ \text { XRD } & \text { X-ray diffraction }\end{array}$


Investigation of Sorption and Diffusion Mechanisms, and Preliminary Economic Analysis January 20, 2017 



\section{MATERIALS RECOVERY AND WASTE FORM DEVELOPMENT CAMPAIGN}

\section{TRITIUM SEPARATION FROM HIGH VOLUME DILUTE AQUEOUS STREAMS}

\section{OBJECTIVE}

The release of tritium [usually as tritiated water (HTO)] from nuclear facilities poses a serious hazard to the environment necessitating tritium abatement on aqueous streams generated from various nuclear operations. As a result, there is a need to control tritium release to the environment. There are several sources of tritium generation in nuclear processing such as light and heavy water reactors, and the International Thermonuclear Experimental Reactor (ITER).

A novel separation process that utilizes molecular sieve membranes capable of preferentially separating tritium from high volume dilute HTO-bearing aqueous streams was evaluated. The use of membranes for radioactive decontamination and tritium separation is detailed in the literature, ${ }^{1-3}$ but the proposed approach of utilizing molecular sieve membranes on robust high-surface area supports has not been reported. Traditional tritium separation technologies include combined electrolysis and catalytic exchange (CECE), palladium membrane reactor (PMR), and the highly energy intensive cryogenic distillation. ${ }^{4-11}$ CECE is generally recognized as the current state of the art for decontamination of tritium in light water and heavy water (HDO) nuclear power reactors where HDO is used both as a reactor moderator and coolant.

An alternative technology utilizing zeolite molecular sieve membranes was evaluated, which may demonstrate significant, low energy improvement over the available technologies for tritium separation. Membrane-based tritium concentration, the subject of this effort, may offer several advantages over the current state of the art. The membrane system is relatively easy to fabricate and directly scalable to handle large volume dilute streams with low operating cost. The low cost operating features include separation and concentration at ambient temperature and low pressure compared to CECE, cryogenic distillation or PMR systems. Tritium removal from light and heavy water reactors is described with the application of combined electrolysis and catalyst exchange in U.S. and Canadian patent applications. ${ }^{5,6}$

The typical concentrations of HTO reported are in the range of 0.54 to $1 \mathrm{Ci} / \mathrm{kg}$ of tritiated water. For the CECE process, the processing cost for tritium recovery/concentration is directly dependent on the volume of tritiated water and thus can be cost prohibitive in applications requiring tritium removal from large volume dilute aqueous solutions.

SAPO-34 is a neutral uncharged zeolite material. ${ }^{10}$ It has been reported that the self-diffusion of several isotopic species of water such as $\mathrm{H}_{2} \mathrm{O}, \mathrm{HDO} / \mathrm{D}_{2} \mathrm{O}$ (heavy water) and $\mathrm{HTO} / \mathrm{T}_{2} \mathrm{O}$ (tritiated water) can be significantly modified in cation exchanged zeolite or molecular sieve sorbents. ${ }^{9}$ The self-diffusion coefficients of $\mathrm{H}_{2} \mathrm{O}$ and $\mathrm{HTO}$ in sorbents such as zeolite 4A can differ by several orders of magnitude depending on the type of cations $\left(\mathrm{Co}, \mathrm{Ni}, \mathrm{Cs}\right.$, etc.) that replace $\mathrm{Na}$ in the zeolite structure. ${ }^{9,13}$ The goal in 
these studies was to evaluate the feasibility of separating tritium by taking advantage of the differences in adsorption and diffusion rates through cation exchanged zeolite molecular sieve membranes.

In the previous milestone reports, it was shown that a high HDO (deuterated water) separation factor of $>10$ using SAPO-34 membranes could be achieved. ${ }^{12}$ The separation factor is the ratio of mole fraction of HDO in the permeate over the mole fraction in the feed and is further discussed in section 2.3. In nuclear fuel reprocessing, process water and acid water streams are recycled and are contaminated with tritiated water. The HTO concentration can be in the range of 200 to $1,000 \mathrm{Ci} / \mathrm{m}^{3}$ or $0.2-1 \mathrm{mCi} / \mathrm{mL}$ The HTO concentration at the upper end of the range was used in this study. It should be noted that these concentrations are at least three orders of magnitude lower than HDO concentration in deuterated water experiments. This research report describes the tritiated water (HTO) separation performance and HTO selectivity with monovalent and divalent cation exchanged SAPO-34 membranes prepared on alumina disk supports to assess their feasibility for the concentration of tritiated water.

\section{MATERIALS AND METHODS}

\subsection{SAPO-34 and ion exchanged SAPO-34 membrane synthesis}

SAPO-34 crystals were first synthesized prior to the preparation of SAPO-34 membranes. Aluminum as aluminum isopropoxide, $\mathrm{H}_{3} \mathrm{PO}_{4}$ (to produce the $\mathrm{P}_{2} \mathrm{O}_{5}$ group), and deionized (DI) water were mixed and stirred for $3 \mathrm{~h}$. LUDOX ${ }^{\circledR}$ colloidal silica was then added and mixed for another $3 \mathrm{~h}$. Triethyl aluminum hydroxide (TEAOH) and di-n-propylamine (DPA) were added to the homogeneous solution and stirred for 4 days as an aging step. The crystals were synthesized at $210{ }^{\circ} \mathrm{C}$ for $24 \mathrm{~h}$ by the hydrothermal synthesis method, and the crystallized seeds were washed and dried. The molar composition of the SAPO-34 crystals synthesis solution was $1.0 \mathrm{Al}_{2} \mathrm{O}_{3}: 1.0 \mathrm{P}_{2} \mathrm{O}_{5}: 0.32 \mathrm{SiO}_{2}: 1.0$ TEAOH:0.8 DPA: $52 \mathrm{H}_{2} \mathrm{O}$.

H-SAPO-34 membranes were prepared by secondary growth on disk-type $\alpha$-alumina supports (25.4 mm diameter and $1 \mathrm{~mm}$ thickness, Coorstek). The substrates were seeded using the smaller-size SAPO-34 crystals via the steam-assisted conversion (SAC) method. The seed crystals were added to a synthesis mixture that had a molar composition of $1.0 \mathrm{Al}_{2} \mathrm{O}_{3}: 2.0 \mathrm{P}_{2} \mathrm{O}_{5}: 0.6 \mathrm{SiO}_{2}: 4.0$ TEAOH:75 $\mathrm{H}_{2} \mathrm{O}$, and the $\mathrm{Al}$ source was alumina isopropoxide, P source was phosphoric acid, and LUDOX AS-40 was used as Si source. The seeds/synthesis mixture ratio was $15 \mathrm{mg} / \mathrm{g}$. After evaporating $90 \%$ water from the mixture at $353 \mathrm{~K}$ and converting the synthesis mixture into a gel-like paste, the disk support was hand-coated with the paste containing the seeds. The substrates were then dried for $2 \mathrm{~h}$ at $323 \mathrm{~K}$ and subsequently placed in Parr autoclaves with $5 \mathrm{~mL}$ of DI water introduced at the bottom. The SAC process was then carried out at $473 \mathrm{~K}$ for $24 \mathrm{~h}$ in order to convert the paste coating into continuous seed layer. Well-intergrown SAPO-34 membranes were then prepared from the post-SAC substrates by contacting them with a synthesis mixture of molar composition $0.85 \mathrm{Al}_{2} \mathrm{O}_{3}: 1.0 \mathrm{P}_{2} \mathrm{O}_{5}: 0.6 \mathrm{SiO}_{2}: 1.75$ TEAOH:155 $\mathrm{H}_{2} \mathrm{O}$. $\mathrm{Al}(\mathrm{OH})_{3}(\mathrm{Al}$ source) and DI water were mixed and stirred for $30 \mathrm{~min}$, followed by phosphorous source addition and stirring for $2 \mathrm{~h}$. The Si source (colloidal silica) was added to the mixture and stirred for additional $30 \mathrm{~min}$. Then TEAOH was added and the mixture was aged for $12 \mathrm{~h}$ at $328 \mathrm{~K}$. The seeded substrate was placed vertically in a Parr autoclave and hydrothermal growth was carried out at $483 \mathrm{~K}$ for $6 \mathrm{~h}$. The membranes were calcined at $823 \mathrm{~K}$ for $6 \mathrm{~h}$ in stagnant air using a slow $0.5 \mathrm{~K} / \mathrm{min}$ heating and cooling rate to avoid potential cracks caused by rapid temperature changes. The acetate salts of various ions $\left(\mathrm{Li}^{+}, \mathrm{Na}^{+}, \mathrm{K}^{+}\right.$, and $\left.\mathrm{Co}^{2+}\right)$ dissolved in ethanol and chloride salts of divalent cations $\left(\mathrm{Mg}^{2+}\right.$ and $\left.\mathrm{Sr}^{2+}\right)$ were used to introduce cations in $\mathrm{H}-$ SAPO-34. For barium cation exchange, barium chloride dissolved in methanol was prepared.

Concentration of metal salts in solvent was $0.05 \mathrm{M}$ for monovalent cations, and $0.01 \mathrm{M}$ for divalent ions. Each membrane was attached on magnetic stirrer using epoxy resin and placed in exchange solution (150 $\mathrm{mL}$ ) in a beaker. The exchange solution was heated to $333 \mathrm{~K}$ and the membranes were stirred at $100 \mathrm{rpm}$. 


\subsection{Membrane characterization}

The SAPO-34 seed crystals and membrane were characterized by X-ray diffraction (XRD), and the synthesized membranes were tested for single-gas permeation in which the driving force is a pressure gradient. The XRD patterns were analyzed solely to confirm the previously known and established phase identification of the synthesized seed crystals. After each of the single-gas permeation tests (using xenon or krypton) the membrane was degassed at $100{ }^{\circ} \mathrm{C}$ in a vacuum. The chamber at the permeate side of the membrane was evacuated, then closed, and target gas was introduced to feed side. During the test, pressure at the feed and permeate sides were recorded over time. This data was used to calculate the membrane permeance and selectivity from a single gas permeation unit. This helps to characterize the membrane properties in terms of selectivity and presence of defects.

Considering the formal charges on the $\mathrm{Si}(4+), \mathrm{Al}(+3), \mathrm{P}(+5)$, and $\mathrm{O}(-2)$ atoms, a net negative framework charge occurs when there are more $\mathrm{Al}$ atoms than $\mathrm{P}$ atoms for a given number of $\mathrm{Si}$ atoms. The negative charges must be balanced by cations (either $\mathrm{H}^{+}$, or a metal cation if present in the synthesis solution) that are occluded in the pores. The SAPO-34 membrane composition can be estimated by EDS analysis and the amount of ion introduced in one unit cell of SAPO-34 is shown in Table 1. The composition of Li-SAPO-34 was not analyzed due to the low energy of characteristic radiation of Li. Single-gas permeation measurements were carried out using in-house built permeation units operating in dead-end mode. The feed pressure was maintained at $150 \mathrm{kPa}$ and the permeate side was at vacuum. The fluxes were obtained by the standard method of measuring the rate of the initial linear pressure rise in a collection vessel on the permeate side after isolating the vacuum. The permeance is then obtained as the ratio of the measured flux and the pressure drop between the feed and permeate side. The permeation properties of each membrane are summarized in Table 1.

The gas permeance of neutral SAPO-34 and cation exchanged SAPO-34 membranes is summarized in Table 2. Ideal selectivity is defined as the ratio of $\mathrm{Kr}$ and Xe permeance. A higher value is indicative of the ability of the synthesized membrane to preferentially permeate $\mathrm{Kr}$ over Xe. It can be seen that the $\mathrm{Kr} / \mathrm{Xe}$ ideal selectivity with cation exchanged SAPO-34 was substantially higher than the neutral SAPO34. The $\mathrm{Kr} / \mathrm{Xe}$ selectivity for monovalent (K, Na, Li) exchanged SAPO-34 ranged from 18 to 25 compared to $<10$ with neutral SAPO-34 zeolite membranes. The $\mathrm{Kr} / \mathrm{Xe}$ selectivity for divalent cations ( $\mathrm{Ba}, \mathrm{Co}, \mathrm{Mg}, \mathrm{Sr}$ ) ranged from 6.8 to 27 . These results clearly show that high quality membranes were synthesized which are well suited to evaluate the vapor sorption and diffusion through the zeolite pores on tritiated water feed. 
Table 1. Composition and single gas permeance of SAPO-34 membranes before and after ion exchange

\begin{tabular}{|c|c|c|c|c|c|}
\hline No. & Exchanged Ion & Composition & $\underset{(\mathbf{G P U})}{\mathbf{P}_{\mathrm{Kr}}}$ & $\underset{(\mathbf{G P U})}{\mathbf{P}_{\mathbf{X e}}}$ & $\begin{array}{c}\text { Ideal } \\
\text { Selectivity } \\
(\mathrm{Kr} / \mathrm{Xe})\end{array}$ \\
\hline \multirow{2}{*}{1} & None & $\mathrm{H}_{4.1} \mathrm{Si}_{2.7} \mathrm{Al}_{18.7} \mathrm{P}_{14.6} \mathrm{O}_{72}$ & 20.2 & 1.44 & 14.0 \\
\hline & $\mathrm{Na}^{+}$ & $\mathrm{H}_{0.6} \mathrm{Na}_{2.9} \mathrm{Si}_{2.7} \mathrm{Al}_{18.4} \mathrm{P}_{15.0} \mathrm{O}_{72}$ & 7.4 & 0.4 & 18.5 \\
\hline \multirow{2}{*}{2} & None & $\mathrm{H}_{4.1} \mathrm{Si}_{2.7} \mathrm{Al}_{18.7} \mathrm{P}_{14.6} \mathrm{O}_{72}$ & 42.4 & 1.80 & 23.6 \\
\hline & $\mathrm{Li}^{+}$ & - & 7.5 & 0.30 & 25.0 \\
\hline \multirow{2}{*}{3} & None & $\mathrm{H}_{4.1} \mathrm{Si}_{2.7} \mathrm{Al}_{18.7} \mathrm{P}_{14.6} \mathrm{O}_{72}$ & 7.7 & 0.7 & 11.3 \\
\hline & $\mathrm{K}^{+}$ & $\mathrm{H}_{0.8} \mathrm{~K}_{3.7} \mathrm{Si}_{2.7} \mathrm{Al}_{18.9} \mathrm{P}_{14.4} \mathrm{O}_{72}$ & 6.8 & 0.27 & 24.8 \\
\hline \multirow{2}{*}{4} & None & $\mathrm{H}_{1.6} \mathrm{Si}_{4.0} \mathrm{Al}_{16.8} \mathrm{P}_{15.2} \mathrm{O}_{72}$ & 23.2 & 1.50 & 15.5 \\
\hline & $\mathrm{Co}^{2+}$ & $\mathrm{H}_{0.4} \mathrm{Co}_{0.4} \mathrm{Si}_{3.6} \mathrm{Al}_{16.8} \mathrm{P}_{15.6} \mathrm{O}_{72}$ & 9.50 & 1.40 & 6.79 \\
\hline \multirow{2}{*}{5} & None & $\mathrm{H}_{4.1} \mathrm{Si}_{2.7} \mathrm{Al}_{18.7} \mathrm{P}_{14.6} \mathrm{O}_{72}$ & 29.4 & 1.70 & 17.3 \\
\hline & $\mathrm{Ba}^{2+}$ & - & 13.8 & 0.51 & 27.1 \\
\hline \multirow{2}{*}{6} & None & $\mathrm{H}_{4.1} \mathrm{Si}_{2.7} \mathrm{Al}_{18.7} \mathrm{P}_{14.6} \mathrm{O}_{72}$ & 31.9 & 1.05 & 30.5 \\
\hline & $\mathrm{Sr}^{2+}$ & - & 18.1 & 0.79 & 22.9 \\
\hline \multirow{2}{*}{7} & None & $\mathrm{H}_{4.1} \mathrm{Si}_{2.7} \mathrm{Al}_{18.7} \mathrm{P}_{14.6} \mathrm{O}_{72}$ & 24.2 & 1.01 & 24.1 \\
\hline & $\mathrm{Mg}^{2+}$ & - & 15.1 & 1.11 & 13.6 \\
\hline
\end{tabular}

Table 2. Gas permeance of neutral SAPO-34, monovalent, and divalent cation exchange SAPO34 zeolite membranes

\begin{tabular}{|c|c|c|c|c|c|c|}
\hline Zeolite Membrane & He, GPU & $\mathbf{N}_{\mathbf{2}}, \mathbf{G P U}$ & $\begin{array}{c}\text { Selectivity } \\
\left(\mathbf{H e}_{\mathbf{N}}\right)\end{array}$ & $\mathbf{K r}, \mathbf{G P U}$ & $\mathbf{X e}, \mathbf{G P U}$ & $\begin{array}{c}\text { Selectivity } \\
(\mathbf{K r} / \mathbf{X e})\end{array}$ \\
\hline SAPO-34 & 85.00 & 33.00 & 2.58 & 12.5 & 1.50 & 8.33 \\
\hline K-SAPO & 48.00 & 20.14 & 2.38 & 6.80 & 0.27 & 25.19 \\
\hline Li-SAPO & 87.00 & 17.00 & 5.12 & 7.50 & 0.30 & 25.00 \\
\hline Na-SAPO & 63.00 & 16.00 & 3.94 & 7.40 & 0.40 & 18.50 \\
\hline Ba-SAPO & 83.26 & 43.09 & 1.93 & 13.8 & 0.51 & 27.06 \\
\hline Mo-SAPO & 47.00 & 11.00 & 4.27 & 9.50 & 1.40 & 6.79 \\
\hline Sr-SAPO & 28.75 & 15.61 & 1.84 & 18.10 & 0.79 & 22.91 \\
\hline
\end{tabular}




\subsection{Analysis of tritiated water samples}

The analysis of HTO concentration in the feed and permeate from the pervaporation system was performed using a Liquid Scintillation Analyzer (LSA). The concentration (radioactivity) was measured in Becquerel $/ \mathrm{mL}(\mathrm{Bq} / \mathrm{mL})$. The error in the measurement of HTO concentration is estimated to be $1-2 \%$, and the error in the calculated HTO permeance is $<5 \%$. Analysis of deuterated water was performed using Fourier Transform Infrared Spectroscopy (FTIR) and is described in detail elsewhere. ${ }^{12}$

The separation factor of $\mathrm{HTO}$ over $\mathrm{H}_{2} \mathrm{O}$ is defined as:

$$
\alpha_{\mathrm{HTO} / \mathrm{H}_{2} \mathrm{O}}=\frac{C_{\mathrm{HTO}}^{P} / C_{\mathrm{H}_{2} \mathrm{O}}^{P}}{C_{\mathrm{HTO}}^{F} / C_{\mathrm{H}_{2} \mathrm{O}}^{F}}
$$

where, $C_{\mathrm{HTO}}^{P}$ and $C_{\mathrm{H}_{2} \mathrm{O}}^{P}$ are concentrations of $\mathrm{HTO}$ and $\mathrm{H}_{2} \mathrm{O}$ in the permeate, respectively, and $C_{\mathrm{HTO}}^{F}$ and $C_{\mathrm{H}_{2} \mathrm{O}}^{\mathrm{F}}$ are concentrations in the feed solution.

\subsection{Pervaporation tests}

The schematic of the pervaporation system used for the permeation and separation measurements on disk molecular sieve zeolite membranes is shown in Figure 1. The system consisted of a feed reservoir, a membrane test cell, and a cold trap to recover the condensed vapor on the permeate side of the membrane. The cold trap consisted of liquid nitrogen-cooled vessel. The vapor pressure of water at this temperature is nearly zero.

The feed volume was in the range of 1.5 to $3 \mathrm{~mL}$. Pervaporation experiments were performed at room temperature $\left(\sim 25{ }^{\circ} \mathrm{C}\right)$. The effective membrane area of the linch disk membrane was $2.85 \mathrm{~cm}^{2}$. The feed HTO concentration was approximately $1 \mathrm{mCi} / \mathrm{mL}(1 \mathrm{Ci} / \mathrm{L})$. This is consistent with the anticipated HTO concentration in the process water and acid recycle streams generated during the processing of used nuclear fuel.

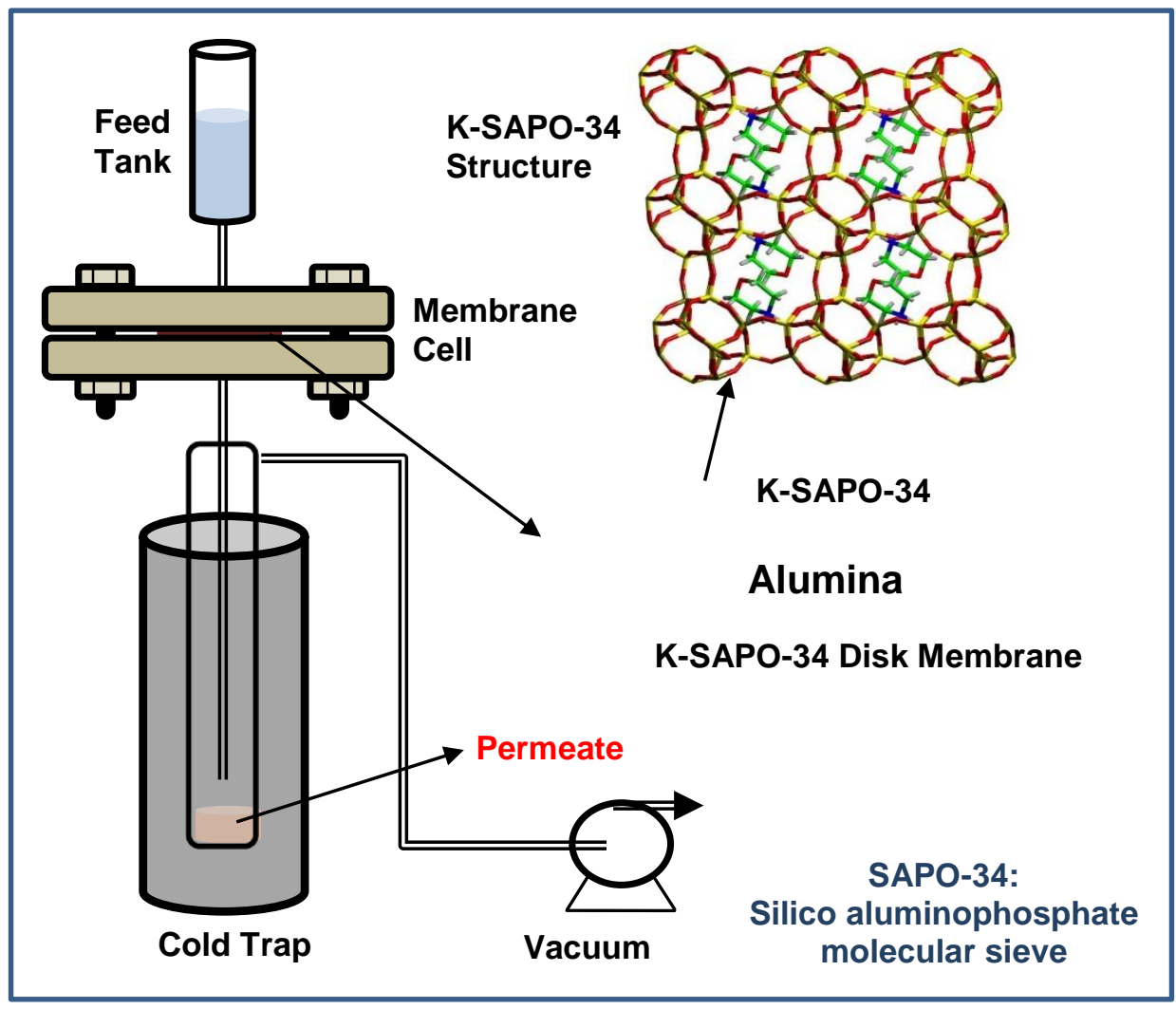


Figure 1. Schematic of the pervaporation system for the separation of tritiated water.

\section{RESULTS AND DISCUSSION}

One of the approaches to increase the preferential diffusion of HTO is to vary the self-diffusion coefficient of water in zeolite pores by incorporating cations such as sodium, potassium, cobalt or cesium $\left(\mathrm{Na}^{+}, \mathrm{K}^{+}, \mathrm{Co}^{2+}, \mathrm{Cs}^{+}\right)$. According to the literature, ${ }^{9}$ diffusion coefficient of water can be tuned by several orders of magnitude when the zeolite structure was exchanged with other cations mentioned above. This is based on the hypothesis that one should expect slower diffusion of water when monovalent cations such as $\mathrm{Na}^{+}, \mathrm{Li}^{+}, \mathrm{K}^{+}$, is replaced with smaller divalent cations such as $\mathrm{Ba}^{2+}, \mathrm{Co}^{2+}$ and $\mathrm{Sr}^{2+},{ }^{9}$ This is due to the fact that small-size polyvalent cations on zeolite framework sites interact strongly with water dipoles, allowing a more compact packing and ordering of water molecules in the pores. It was hypothesized that these approaches would allow modification and optimization of the characteristics of SAPO-34 membranes in terms of both adsorption and diffusion selectivity.

An important requirement for the economic viability of a membrane-based separation system is high permeance to deliver high throughput and process efficiency. $\mathrm{HTO}$ and $\mathrm{H}_{2} \mathrm{O}$ permeance is a critical measure that will impact the capital and operating cost. In this report, results obtained on disk membranes are discussed. Scale-up studies in the tubular module configuration would offer a significant advantage due to the high packing density and ease of scalability.

Table 3 shows the results of pervaporation experiments with monovalent cations $\left(\mathrm{K}^{+}, \mathrm{Li}^{+}, \mathrm{Na}^{+}\right)$exchanged SAPO-34 zeolite membranes. The feed tritiated water was $\sim 1 \mathrm{mCi} / \mathrm{mL}$. Separation factor $\left(\mathrm{HTO} / \mathrm{H}_{2} \mathrm{O}\right)$ for the tritiated water separation with neutral SAPO-34 zeolite membrane was 0.83 which indicates that HTO did not preferentially permeate through zeolite pores over $\mathrm{H}_{2} \mathrm{O}$. The calculated $\mathrm{H}_{2} \mathrm{O}$ permeance was lower than HTO permeance resulting in the ideal selectivity value of $0.99(<1)$. However, the trend became reverse after ion exchange with monovalent cations. The ideal selectivity for $\mathrm{HTO} / \mathrm{H}_{2} \mathrm{O}$ separation was higher than 1 for all cases and also higher than the Knudsen selectivity. For example, the Knudsen selectivity for $\mathrm{HTO} / \mathrm{H}_{2} \mathrm{O}$, which is based on the ratio of the square root of molecular weights is 1.05 . Thus, the synthesized membrane displayed some molecular sieving effect as ideal selectivity values up to 1.23 were obtained. 
Table 3. Vapor permeation characteristics of SAPO-34 monovalent ion exchange SAPO-34 zeolite membranes

\begin{tabular}{lcccccc} 
Membrane & SAPO- & SAPO- & K-SAPO- & Li-SAPO- & Li-SAPO- & Na-SAPO- \\
& $\mathbf{3 4}$ & $\mathbf{3 4}$ & $\mathbf{3 4}$ & $\mathbf{3 4}$ & $\mathbf{3 4}$ & $\mathbf{3 4}$ \\
$\mathbf{p H}$ & 7 & 4 & 7 & 7 & 4 & 7 \\
$\begin{array}{l}\text { HTO in } \\
\text { Retentate } \\
(\mathrm{mCi} / \mathrm{ml})\end{array}$ & 1.135 & 1.054 & 1.162 & 1.165 & 1.135 & 1.178 \\
$\begin{array}{l}\text { HTO in } \\
\text { Permeate } \\
\text { (mCi/ml) }\end{array}$ & 0.946 & 0.946 & 1.189 & 1.122 & 1.135 & 1.135 \\
$\begin{array}{l}\text { HTO } \\
\text { Permeance }\end{array}$ & 115.83 & 190.89 & 2087.12 & 2134.47 & 3752.77 & 1827.97 \\
(GPU) & & & & & & \\
$\begin{array}{l}\text { H2O Permeance } \\
\text { (GPU) }\end{array}$ & 116.01 & 177.50 & 1701.52 & 1849.56 & 3130.80 & 1583.27 \\
$\begin{array}{l}\text { Separation } \\
\text { Factor }\end{array}$ & 0.83 & 0.89 & 1.023 & 0.96 & 1 & 0.96 \\
Ideal Selectivity & 0.99 & 1.08 & 1.23 & 1.15 & 1.20 & 1.15 \\
\hline
\end{tabular}

Interestingly, all monovalent cation exchanged SAPO-34 membranes showed drastic increase in vapor permeance for both components. It is different from the results of gas permeance, which showed highly reduced permeance of inert gases after ion exchange. In gas permeation, the introduced cations blocked the pathways of passing gas molecules, which caused reduced diffusivity and permeance. However, the metal cations in SAPO-34 could have different effect on the adsorption and diffusion behavior of $\mathrm{H}_{2} \mathrm{O}$ and HTO. At neutral $\mathrm{pH}$, the permeance of HTO was only 115 GPU while it became $1827-2134$ GPU after ion exchange. Electronegativity of oxygen atom in ion-exchanged SAPO-34 framework is higher than that in neutral SAPO-34 framework. Metal cations thus might have strong adsorption sites for water and tritiated water molecules via electrostatic interactions at the solid-water interface, since water molecules could be strongly polarized due to the high electronegativity of the oxygen atom in the framework. This would lead to a strong interaction of water with cationic adsorption sites rather than with neutral surfaces of SAPO-34 zeolite, resulting in improved permeance of $\mathrm{H}_{2} \mathrm{O}$ and HTO molecules.

Table 4 summarizes the pervaporation experimental results for SAPO-34 membrane exchanged with divalent cations $\left(\mathrm{Co}^{2+}, \mathrm{Ba}^{2+}\right.$, and $\left.\mathrm{Sr}^{2+}\right)$. Similar to the results from Table 3, the separation factor increased and ideal selectivity were larger than 1 for $\mathrm{HTO} / \mathrm{H}_{2} \mathrm{O}$ separation after ion exchange. The permeance increase was also observed after divalent cation exchange, but the increase was smaller compared to monovalent cation case. This might be attributed to the number of divalent cations accessible to zeolite framework which is about half that of monovalent cations due to their valence. Therefore, the water molecules would be less strongly polarized and less strongly adsorbed to the divalent cation-exchanged SAPO-34 framework compared to monovalent cation-exchange SAPO-34, but strongly adsorbed than neutral SAPO-34. The effect of different cations on the adsorption and diffusion of $\mathrm{H}_{2} \mathrm{O}$ and HTO (possibly $\mathrm{D}_{2} \mathrm{O}$ ) in the SAPO-34 framework will be further studied with other cation exchanged materials. 
Table 4. Vapor permeation characteristics of SAPO-34 divalent cation exchange SAPO-34 zeolite membranes

\begin{tabular}{|c|c|c|c|c|c|c|}
\hline Membrane & $\begin{array}{l}\text { SAPO- } \\
34\end{array}$ & $\begin{array}{l}\text { Co- } \\
\text { SAPO-34 }\end{array}$ & $\begin{array}{l}\text { Co-SAPO- } \\
34\end{array}$ & $\begin{array}{l}\text { Ba-SAPO- } \\
34\end{array}$ & $\begin{array}{l}\text { Ba-SAPO- } \\
\mathbf{3 4}\end{array}$ & $\begin{array}{l}\text { Sr-SAPO- } \\
\quad 34\end{array}$ \\
\hline pH & 7 & 7 & 4 & 7 & 4 & 7 \\
\hline $\begin{array}{l}\text { HTO in } \\
\text { Retentate } \\
(\mathrm{mCi} / \mathrm{ml})\end{array}$ & 1.135 & 1.216 & 1.162 & 1.135 & 1.135 & 1.135 \\
\hline $\begin{array}{l}\text { HTO in } \\
\text { Permeate } \\
(\mathrm{mCi} / \mathrm{ml})\end{array}$ & 0.946 & 1.081 & 1.108 & 1.081 & 1.054 & 1.081 \\
\hline $\begin{array}{l}\text { HTO } \\
\text { Permeance } \\
(\text { GPU })\end{array}$ & 115.83 & 348.88 & 334.25 & 304.44 & 311.74 & 172.13 \\
\hline $\begin{array}{l}\mathrm{H}_{2} \mathrm{O} \text { Permeance } \\
\text { (GPU) }\end{array}$ & 116.01 & 327.54 & 292.49 & 266.71 & 279.84 & 150.80 \\
\hline $\begin{array}{l}\text { Separation } \\
\text { Factor }\end{array}$ & 0.83 & 0.89 & 0.95 & 0.95 & 0.93 & 0.95 \\
\hline Ideal Selectivity & 0.99 & 1.07 & 1.14 & 1.14 & 1.11 & 1.14 \\
\hline
\end{tabular}

Although the separation mechanism is still not well understood, the significant increase in permeance and an increase in $\mathrm{HTO} / \mathrm{H}_{2} \mathrm{O}$ selectivity (above Knudsen diffusion) in cation exchanged SAPO-34 compared to neutral SAPO-34 can be attributed to the presence of new electrostatic interactions between $\mathrm{H}_{2} \mathrm{O} / \mathrm{HTO}$ and surface oxygen atoms of SAPO-34, and decreased pore sizes upon cation exchange. Unfortunately, with the SAPO-34 zeolites, there is a constraint (0.1-0.2 cations/Al atom) on how many cations can be exchanged limiting the variations in electrostatic interactions and also the pore sizes. In order to capitalize on the effect of cation exchange and its beneficial impact on HTO permeance and selectivity, fabrication of the cation exchanged LTA zeolite membranes is currently in progress. In the alumino-silicate framework of LTA, there is a negative charge available for each aluminum atom providing a significantly high exchange capacity of one cation per aluminum atom. In addition, the pore size of LTA zeolite can be decreased to about $0.3 \mathrm{~nm}$, for example when exchanged with potassium ${ }^{14}$. Through the quantum mechanics studies, it was shown that heavy water is more structured liquid than light water and the bond length of $\mathrm{H}_{2} \mathrm{O}$ is greater than that of $\mathrm{D}_{2} \mathrm{O}^{15}$. Another conspicuous difference between $\mathrm{H}_{2} \mathrm{O}$ and $\mathrm{HTO}$ is the frequency of stretching vibration of $\mathrm{O}-\mathrm{H}$ and $\mathrm{O}-\mathrm{T}$ bond which is inversely proportional to the reduced mass $\mu\left[\mu=m_{1} \cdot m_{2} /\left(m_{1}+m_{2}\right), m_{1}\right.$ and $m_{2}$ are masses of bonding atoms]. These identified differences resulting in varied interactions with cation exchanged LTA zeolite surface oxygen atoms and manipulated pore sizes could be utilized to further enhance the $\mathrm{HTO} / \mathrm{H}_{2} \mathrm{O}$ selectivity. Interestingly, NaA zeolite (NaLTA) has been already used in many commercial plants for the selective removal of water from solvents ${ }^{16}$. Thus, the successful evaluation of cation exchanged LTA membrane for the concentration of tritiated water would enable further development of more compact tubular LTA zeolite membranes for a larger scale demonstration.

\section{PRELIMINARY ECONOMIC ANALYSIS}

The two key performance metrics for the separation of tritiated water are vapor permeance and selectivity. Higher selectivity for HTO over $\mathrm{H}_{2} \mathrm{O}$ would have a major impact on the separation efficiency 
as it will minimize the number of stages required to achieve the desired final concentration factor. On the other hand, a high vapor permeance is also essential for the economic viability as it has somewhat greater impact on the system size and cost. Efforts were focused on optimization of both permeation and separation properties of the synthesized membranes zeolite membranes.

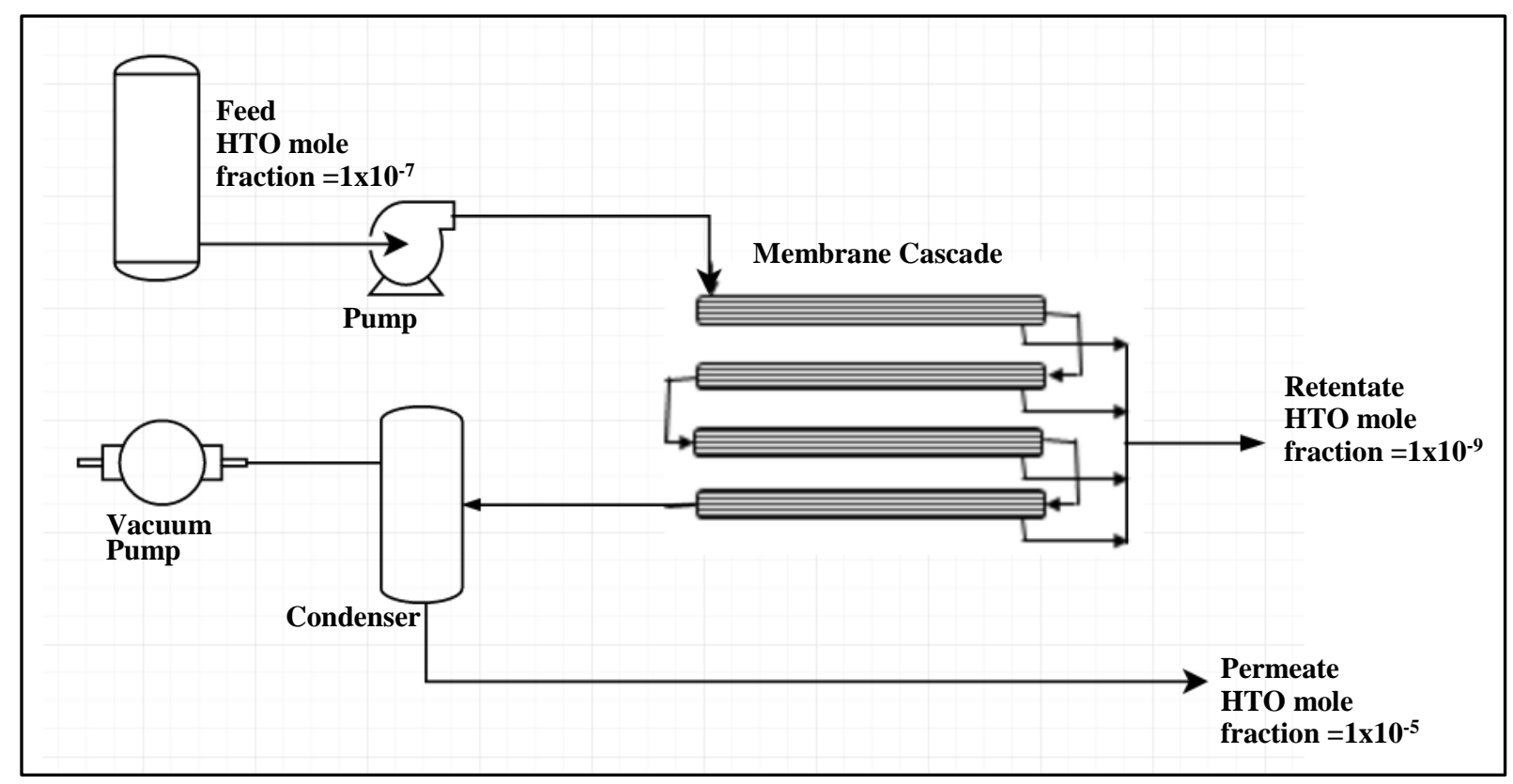

Figure 2. Schematic of a cascade system showing membrane based concentration of tritiated water.

The preliminary economic analysis for the concentration of tritiated water was based on the following assumptions. The flow rate of tritiated water of $10 \mathrm{~L} / \mathrm{min}$ with a feed HTO concentration of $10^{-7}$ mole fraction $\left(10^{-5}\right.$ mole $\left.\%\right)$ which corresponds to HTO concentration of about $1 \mathrm{mCi} / \mathrm{mL}$. The desired concentration factor is 100 which would result in a 100 -fold concentrated permeate or $99 \%$ removal of HTO from the feed into the permeate. The schematic of the membrane-based process for the concentration of tritiated water is shown in Figure 2.

Table 5. Preliminary estimate of membrane area and stages for the concentration of tritiated water

\begin{tabular}{ccccc}
\hline Case & HTO permeance [GPU] & Selectivity & Total Stages & Total Area $\left[\mathbf{m}^{2}\right]$ \\
\hline 1 & 2000 & 10 & 10 & 33.40 \\
2 & 1000 & 10 & 8 & 66.80 \\
3 & 1000 & 5 & 42 & 151.70 \\
4 & 500 & 10 & 10 & 133.58 \\
5 & 500 & 5 & 42 & 303.42 \\
\hline
\end{tabular}

Table 5 illustrates the impact of key process parameters, namely, permeance and selectivity, on the number of stages and required total membrane area to achieve the desired HTO concentration factor. As can be seen, with a HTO selectivity of 5-10 and a HTO permeance of 500 to $2000 \mathrm{GPU}$, it is possible to achieve the tritiated water concentration factor of 100 in 8 to 42 stages and total membrane area ranging 
from about 33 to $303 \mathrm{~m}^{2}$. Although the selectivity values obtained are lower than expected, the results to date have been encouraging, and show that hydrophilic cation exchanged zeolite membranes can deliver high HTO permeance in the range of 2000-3000 GPU. Since typically an increase in selectivity is accompanied by a substantial decrease in permeance, even with a 4-fold drop in HTO permeance to about $500 \mathrm{GPU}$, it is estimated that the concentration of tritiated water can be achieved in a relatively small footprint. The membrane based separation system is estimated to be substantially lower in cost compared to the CECE process, where the processing cost for tritium recovery/concentration is directly proportional to the total volume. The process also requires careful balance of concentration profiles in the column which is packed with a hydrophobic catalyst and inert packing material to promote isotopic exchange between the aqueous solution and gaseous hydrogen.

The estimated system cost for the membrane-based system will be driven by three major components, namely, zeolite membrane elements in a housing, feed pump, vacuum pumps for each stage and a control system. The zeolite membrane will be fabricated on multichannel inorganic supports with 2-4 mm diameter channels ranging from 20 to 60 per membrane element. It is estimated that the membrane module cost would range from $\$ 1000-2000 / \mathrm{m}^{2}$ of membrane area, depending on the system size. The primary energy cost for this system would be vacuum pumps for vapor condensation using liquid nitrogen for the recovery of concentrated HTO in the permeate. Energy costs are estimated at $\$ 24,000 / \mathrm{yr}$ for a 10 $\mathrm{L} / \mathrm{min}$ tritiated water treatment capacity for a system containing 10 stages. Depending on the selectivity and vapor permeance (as shown in Table 5), the average capital cost for the membrane system is estimated to be in the range of $\$ 700,000$ to $\$ 1,100,000$ for a $10 \mathrm{~L} / \mathrm{min}$ tritiated water feed containing $10^{-5}$ mole\% HTO. The operating cost of the membrane system would be relatively low, due to low energy requirements and only major consumable such as liquid nitrogen. The cost comparison with the CECE system will be performed at a later date due to the lack of availability of representative cost and performance data at this time.

\section{FUTURE STUDIES}

In order to increase the selectivity and separation factor of $\mathrm{HTO} / \mathrm{H}_{2} \mathrm{O}$, several approaches will be pursued in the next milestone period. 1) The effort on synthesis of improved cation exchange zeolite membranes will be continued to further tune the self-diffusion coefficient of water versus HTO while reducing the membrane thickness. 2) Additional materials such as LTA (silicoaluminate) zeolites will be fabricated and evaluated to increase the selective adsorption and diffusion of $\mathrm{HTO}$ over $\mathrm{H}_{2} \mathrm{O}$. 3) Following the demonstration of the desired permeance (>1000 GPU) and separation characteristics $\left(\mathrm{HTO} / \mathrm{H}_{2} \mathrm{O}\right.$ selectivity $>5$ ) on disk membranes, tubular zeolite membranes which have higher surface area than disk membranes will be fabricated and evaluated. 4) In order to increase $\mathrm{H}_{2} \mathrm{O}$ rejection, the incorporation of molecular sieve carbon coating on zeolite layer will also be evaluated. This would have the added benefit of superior membrane stability in acid contaminated water recycle streams.

Acknowledgements: The authors wish to thank Vishwanath Deshmane and Lawrence Powell (ORNL) for their extensive contributions in pervaporation experiments, Marc Chattin for Liquid Scintillation analysis, and Yeon Hye Kwon (graduate student at Georgia Tech) for her assistance in membrane synthesis and data analysis.

\section{REFERENCES}

1) Trznadel, G. Z., Tritium removal from water solutions, Desalination, 200, 737-738 (2006).

2) Ambashta, R. D., et al. Membrane purification in radioactive waste management: a short review, Journal of Environmental Radioactivity, 105, 76-84 (2012). 
3) Rana, D., et al. Radioactive decontamination of water by membrane processes- A review, Desalination, 321, 77-92 (2013).

4) Butler, J.P. et al. Apparatus for removal and recovery of tritium from light and heavy water, US patent 4190515 (1980).

5) Bell, A.C., Perevenzentsev, A.N. Method and apparatus for concentrating tritiated water, European Patent Appl. EP 1,736,439 A2, December 27 (2006).

6) Drake, R.H., Recovery of tritium from tritiated waste water cost-effectiveness analysis, Los Alamos National Laboratory LA-UR-97-3767, June (1996).

7) Birdsell, S.A., et al. Tritium recovery from tritiated water with a two-stage palladium membrane reactor, Fusion Engineering and Design, 39-40, 1041-1048 (1998).

8) Embury, M.C., et al. Tritium recovery by cryogenic hydrogen isotope distillation, Proceedings of AIChE winter annual meeting, Miami, November 2-7 (1986).

9) Todorovic, M., et al. The release of tritiated water from cobalt (II) exchanged $4 \mathrm{~A}$ zeolite into surrounding water, Environmental Pollution (Series B) 7, 193-204 (1984).

10) Crawford, P., et al. Zeolite membranes for the separation of radioactive krypton and xenon, Proceedings of the Annual Meeting of the American Nuclear Society, Reno, June 15-19 (2014).

11) Wee, S., et al. Membrane separation process-pervaporation through zeolite membrane, Separation and Purification Technology, 63, 500-516 (2008).

12) Bhave, R., et. al. Tritium separation from high volume dilute aqueous solutions, FCRDMRWFD-2015-000391; FCRD-MRWFD-2015-000392).

13) Mills, R., Self-diffusion in normal and heavy water in the range of 1-45, Journal of Physical Chemistry, 77(5), 685-688 (1973).

14) Wang N., et al. Hydrophilic SOD and LTA membranes for membrane-supported methanol, dimethylether and dimethylcarbonate synthesis., Microporous and Mesoporous Materials 207, 33 38 (2015).

15) Soper A. K. and Benmore C. J., Quantum Differences between Heavy and Light Water, Physical Review Letters 101(6), 065502 (2008).

16) Morigami, Y. et al., The first large-scale pervaporation plant using tubular-type module with zeolite NaA membrane separation, Separation \& Purification Technol., 25, 251-260 (2001). 